Jurnal Farmasi Galenika (Galenika Journal of Pharmacy) 2018; 4 (2): 93 - 97

ISSN : 2442-8744 (electronic)

http://jurnal.untad.ac.id/jurnal/index.php/Galenika/index

DOI : $10.22487 / \mathrm{j} 24428744.10590$

\title{
Sinergitas Aktivitas Antibakteri dari Kelopak Bunga Rosella dan Kitosan Terhadap Staphylococcus aureus
}

\author{
(Synergistic Antibacterial Activity of Roselle Calyx and Chitosan against Staphylococcus \\ aureus )
}

\author{
Haeriah, Natsir Djide, Gemini Alam, Sartini
}

Fakultas Farmasi, Universitas Hasanuddin, Makassar, Indonesia, 90245

\section{Article Info:}

Received: 24 Agustus 2018

in revised form: 20 September

Accepted: 27 September 2018

Available Online:30 September 2018

Keywords:

Hibiscus sabdariffa L.

Kitosan

Staphylococcus aureus

Sinergitas antibakteri

Corresponding Author:

Sartini

Fakultas Farmasi

Universitas Hasanuddin

Makassar 90245

sardj@farmasi.unhas.ac.id

\begin{abstract}
Currently, the antibacterial research is increasingly promoted primarily from natural materials, due to the increasing number of pathogenic bacteria that have been resistant to existing antibiotics. One of the pathogenic bacteria that has been much resistant to antibiotics is Staphylococcus aureus. Roselle calyx (Hibiscus sabdariffa L.) and chitosan are known to have antibacterial activity. The aim of this study to find out the antibacterial synergy of the rosella calyx extract and chitosan against. S.aureus ATCC 33592. Roselle calyx was extracted by maceration using $80 \%$ ethanol, while chitosan is obtained from deasetilation of chitin from shrimp husk. Test antibacterial synergism using checkboard assay method by calculating the minimum inhibitory concentration (MIC) using microdilution assay. The results showed minimum inhibitory concentration (MIC) value of roselle calyx extract and chitosan were $1250 \mathrm{ppm}$ and 50 ppm, respectively. MIC value of roselle calyx extract in the presence of chitosan was $625 \mathrm{ppm}$, while the value of MIC chitosan in the presence of roselle calyx extract was $<0.19 \mathrm{ppm}$. Fractional Inhibition Concentration Index (FICI) was $<0.5$ that mean the combination of roselle calyx extract with chitosan has a synergistic antibacterial effect on S.aureus ATCC 33592.
\end{abstract}

Copyright (C) 2017 JFG-UNTAD

This open access article is distributed under a Creative Commons Attribution (CC-BY-NC-SA) 4.0 International license.

How to cite (APA 6th Style):

Haeriah, et al. (2018). Sinergitas Aktivitas Antibakteri dari Kelopak Bunga Rosella dan Kitosan Terhadap Staphylococcus aureus. Jurnal Farmasi Galenika : Galenika Journal of Pharmacy, 4(2), 93-97. doi:10.22487/j24428744.2018.v4.i2.10590 


\begin{abstract}
ABSTRAK
Saat ini pencarian antibakteri makin digalakkan utamanya dari bahan alam, disebabkan makin banyaknya antibiotika yang mengalami resistensi terhadap bakteri patogen, antara lain: Staphylococcus aureus. Kelopak bunga Rosella (Hibiscus sabdariffa L.) dan kitosan diketahui memiliki aktivitas antibakteri. Tujuan dari penelitian ini adalah mengetahui sinergitas antibakteri dari ekstrak kelopak bunga rosella dan kitosan terhadap S. aureus ATCC 33592. Kelopak bunga rosella diekstraksi secara maserasi menggunakan etanol 80\%, sedangkan kitosan diperoleh dari deasetilasi kitin kulit udang. Kadar hambat minimal (KHM) dilakukan dengan metode mikrodilusi dan dilanjutkan uji sinergitas antibakteri menggunakan metode microdilution checkboard assay. Hasil penelitian diperoleh nilai KHM (kadar hambat minimal) ekstrak kelopak bunga rosella dan kitosan berturut-turut sebesar 1250 bpj dan 50 bpj. Nilai KHM ekstrak kelopak bunga rosella dengan adanya kitosan yaitu 625 bpj, sedangkan nilai KHM kitosan dengan adanya ekstrak kelopak bunga rosella yaitu $<0,19$ bpj. Indeks Kadar hambat Fraksional (FICI) adalah $<0,5$ yang disimpulkan bahwa kombinasi dari ekstrak kelopak bunga rosella dengan kitosan memiliki efek antibakteri sinergis terhadap S.aureus ATCC 33592.
\end{abstract}

Kata Kunci : : Hibiscus sabdariffa L., kitosan, Staphylococcus aureus, sinergitas antibakteri

\section{PENDAHULUAN}

Resistensi antibiotika menjadi salah satu masalah yang sangat serius. Saat ini, banyak bakteri yang telah mengalami resisten terhadap berbagai jenis antibiotika, salah satunya adalah Staphylococcus aureus. Salah satu peluang yang dapat digunakan untuk menekan terjadinya bakteri yang resisten terhadap antibiotika yang ada adalah pemanfaatan bahan alam sebagai alternatif antibakteri. Penelitianpenelitian bahan alam sebagai antibakteri, antara lain: kelopak bunga rosella (Borrás-Linares et al., 2015) dan kitosan (Kong, Chen, Xing, \& Park, 2010).

Tanaman rosella (Hibiscus sabdariffa L.) mengandung senyawa fenolik, antara lain: antosianin (delphinidin-3-O-sambubioside dan Cyanidin--3-Osambubioside), flavonoid (kuersetin, luteolin, gossipetin), asam protokatekuat (Borrás-Linares et al., 2015; Jabeur et al., 2017; Sindi, Marshall, \& Morgan, 2014). Penelitian yang dilakukan BorrásLinares et al. (2015), diperoleh bahwa ekstrak dari 25 varitas kelopak bunga rosella memiliki aktivitas antibakteri terhadap bakteri gram negatif (Escherichia coli, Salmonella enteritidis) dan bakteri gram positif (Staphylococcus aureus, Micrococcus luteus). Penelitian Liu, Tsao, \& Yin, (2005) memperoleh ekstrak air kelopak bunga rosella memiliki kadar hambat minimal $32 \pm 8$ bpj terhadap Methicillin Resistant Staphylococcus aureus.
Kitosan dapat diperoleh salah satunya dari limbah kulit udang dengan cara melakukan deasetilasi kitin (Goy, Britto, \& Assis, 2009). Produksi kitosan dari kitin limbah kulit udang telah dilakukan Haeriah et al (2017) dan memiliki aktivitas antibakteri terhadap Staphylococcus aureus. Kitosan yang berasal dari limbah kulit udang memiliki aktivitas antibakteri yang lebih tinggi terhadap bakteri gram positif seperti S.aureus dibandingkan bakteri gram negatif seperti Escherichia coli dan aktivitas antibakteri senyawa kitosan tidak berbeda nyata dengan kontrol positif Vankomisin. kitosan pada konsentrasi 288 bpj memiliki aktivitas antibakteri terhadap $S$. aureus sebesar $14 \mathrm{~mm}$, konsentrasi hambat minimal (KHM) dari senyawa kitosan terhadap bakteri $S$. aureus yaitu sebesar 20 bpj (Goy, Morais, \& Assis, 2016).

Kombinasi dua bahan antibakteri biasanya dilakukan untuk mengurangi dosis yang dibutuhkan atau untuk mengurangi efek samping jika diberikan dalam bentuk tunggal. Permasalahannya adalah apakah kombinasi ekstrak kelopak bunga rosella dengan kitosan memiliki efek sinergis sebagai antibakteri terhadap bakteri uji S.aureus ATCC 33592.

Tujuan penelitian ini untuk mengetahui efek sinergitas kombinasi ekstrak kelopak bunga rosella (Hibiscus sabdariffa L.) dengan kitosan terhadap penghambatan pertumbuhan Staphylococcus aureus ATCC 33592 . 


\section{METODE PENELITIAN}

\section{Alat dan Bahan}

Biosafety cabinet $\left(\right.$ Envirco $\left.^{\circledR}\right)$, oven $\left(\right.$ Ecocell $\left.^{\circledR}\right)$, inkubator $\left(\right.$ Memmert $\left.{ }^{\circledR}\right)$, autoklaf $\left(25 \mathrm{X}-2^{\circledR}\right)$, timbangan analitik $\quad\left(\right.$ Sartorius $\left.^{\circledR}\right)$, mikropipet $\left(\right.$ Memmert $\left.^{\circledR}\right)$, kitosan, simplisia kelopak bunga rosella, etanol 80\%, medium Muller Hinton Btroth (MHB) Triphenyltetrazolium chloride $\left(\right.$ Merck $\left.^{\circledR}\right)$, well microplate 96, air suling steril, asam asetat glasial 1\%, Staphylococcus. aureus ATCC 33592,d 11.

\section{Prosedur}

\section{Ekstraksi Kelopak Bunga Rosella}

Simplisia serbuk kelopak bunga rosella sebanyak 100 gram diayak menggunakan nomor mesh 20 selanjutnya diekstraksi secara maserasi menggunakan $1 \mathrm{~L}$ etanol $80 \%$. Hasil ekstraksi diuapkan pelarutnya dengan evaporator, sehingga diperoleh ekstrak kental.

\section{Analisis kadar total polifenol ekstrak kelopak bunga rosella .}

Ekstrak kelopak bunga rosella sebanyak $100 \mathrm{mg}$ dalam metanol $\mathrm{P}$ hingga volume mencapai $10 \mathrm{ml}$ (10.000 bpj). Kemudian sebanyak 0,4 ml dari larutan stok diambil dan ditambahkan 2,5 ml reagen FolinCiocalteau, diamkan selama 8 menit dan ditambahkan $2 \mathrm{ml}$ larutan natrium hidroksida, kemudian dicukupkan dengan air suling hingga volume menjadi $5 \mathrm{ml}$ (800 bpj). Setelah itu, diinkubasi selama 30 menit pada suhu ruangan lalu diukur absorbansinya dengan menggunakan spektrofotometer UV-Vis pada panjang gelombang $648 \mathrm{~nm}$. Sebagai larutan standar digunakan asam gallat konsentrasi 1,5 - 15 bpj (Kemenkes, 2011).

\section{Penentuan Kadar Hambat Minimal ekstrak rosella, kitosan dan kombinasnya terhadap $S$. aureus}

Efek sinergitas ekstrak rosella dengan kitosan dari limbah kulit udang dilakukan dengan menggunakan metode Microdilution Checkerboard Assay menurut metode Valgas, Souza, Smânia, \& Smânia Jr, (2007) dan Olga, Petar, Jelena, \& Srdjan, (2008) dengan beberapa modifikasi. Dibuat seri konsentrasi ekstrak dengan perbedaan antar konsentrasi 2 kalinya, yaitu untuk rosella : $312,5 \mathrm{bpj}$ s/d $5000 \mathrm{bpj}$, sedangkan kitosan dimulai 0,19 bpj s/d 100 bpj. Volume total setiap well yaitu $100 \mu \mathrm{l}$ yang terdiri atas $5 \mu \mathrm{l}$ larutan ekstrak rosella atau $5 \mu$ l larutan kitosan, $90 \mu$ l medium Muller Hinton Broth (MHB) yang mengandung Staphylococcus aureus setara dengan McFarland $10^{5} \mathrm{CFU} /$ well Kemudian microplate diinkubasi pada suhu $37^{\circ} \mathrm{C}$ selama $1 \times 24$ jam. Setelah inkubasi ditambahkan reagen Triphenyltetrazolium chloride (TTC) sebanyak $5 \mu \mathrm{L}$ kemudian diinkubasi selama 30 menit. Microplate dapat diamati secara visual dengan melihat warna merah muda yang terbentuk dalam menentukan nilai KHM. Konsentrasi terendah yang memperlihatkan warna bening dan tidak berwarna merah muda merupakan nilai KHM nya. Adanya perubahan warna pada medium yang ditumbuhi bakteri tersebut didasarkan atas reduksi dari reagen TTC oleh enzim dehidrogenase yang dihasilkan oleh bakteri yang hidup. Reduksi TTC tersebut membentuk senyawa trifenilformazan yang berwarna merah /pink (Olga et al., 2008).

\section{Penentuan fractional inhibition concentration index (FICI)}

Penentuan nilai FICI dari kombinasi antara kombinasi ekstrak kelopak bunga rosella dengan kitosan dapat dilakukan dengan menggunakan rumus sebagai berikut:

$F I C I=F I C(A)+F I C(B)$

FIC $(A)=$

(KHM Rosella dalam kombinasi dengan Kitosan)

$F I C(B)=$

(KHM Kitosan dalam kombinasi dengan Rosella) KHM Kitosan

Kemudian hasil dari perhitungan nilai FICI kombinasi kedua ekstrak dapat menunjukkan efek yang dihasilkan pada kombinasi kedua ekstrak tersebut. Adapun hasilnya dapat diinterpretasikan sebagai berikut: Sinergis : FICI $\leq 0,5$; Antagonis : FICI $>4$ Aditif : $>0,5$ FICI $\leq 1$ berbeda $:>1$ FICI $\leq 4$ (Bakarnga-Via et al., 2016).

\section{HASIL DAN PEMBAHASAN}

Hasil ekstraksi dan penentuan kadar polifenol total dari ekstrak kelopak bunga rosella diperoleh ekstrak dengan konsistensi kental dengan rendemen ekstrak $22,99 \%$ dan kadar total polifenolnya adalah $10.10 \pm$ $0.2 \mathrm{mg}$ ekivalen asam gallat (EAG) / gram ekstrak, sedangkan penelitian yang dilakukan oleh Jung, Kim, \& Joo, (2013) didapatkan hasil bahwa ekstrak kelopak bunga rosella konsentrasi $7.27 \pm 0.20 \mathrm{mg}$ 
EAG / g ekstrak . Adanya perbedaan kadar polifenol yang diperoleh dapat disebabkan karena perbedaan konsentrasi etanol yang digunakan, rasio simplisia / cairan penyari, dan jenis dan umur tanaman.

Hasil uji KHM dan uji sinergitas dengan metode microdilution checkboard assay diperoleh hasil seperti pada tabel 1 .

Tabel 1. Konsentrasi hambat minimal (KHM) ekstrak kelopak bunga rosella dan kitosan tunggal dan kombinasinya terhadap $S$. aureus

\begin{tabular}{lc}
\hline \multicolumn{1}{c}{ Sampel Uji } & KHM (bpj) \\
\hline Ekstrak Kelopak Bunga Rosella & 1250 \\
Ekstrak Kelopak Bunga Rosella & 625 \\
dengan adanya Kitosan 0,19 bpj & \\
Kitosan & 50 \\
Kitosan dengan adanya Ekstrak & $<0,19$ \\
Kelopak Bunga osella 625 bpj & \\
\hline
\end{tabular}

Nilai KHM dari ekstrak kelopak bunga rosella terhadap S. aureus diperoleh 1250 bpj, sedangkan penelitian (Liu et al., 2005) memperoleh ekstrak air kelopak bunga rosella memiliki KHM $32 \pm 8$ bpj terhadap Methicillin Resistant Staphylococcus aureus. Adanya perbedaan ini antara lain disebabkan adanya perbedaan jenis kelopak bunga rosella, jenis cairan penyari, galur bakteri uji yang digunakan.

Nilai KHM Ekstrak Kelopak bunga rosella dengan adanya kitosan 0,19 bpj adalah $625 \mathrm{bpj}$, menurun 2 kalinya dengan kata lain aktivitasnya meningkat 2 kalinya.

Nilai KHM kitosan terhadap S. aureus 50 bpj , hasil penelitian oleh No, Park, Lee, \& Meyers, (2002) diperoleh KHM kitosan 500 s/d 1000 bpj tergantung dari jenis bakteri dan bobot molekul kitosan. Nilai KHM kitosan dengan adanya ekstrak rosella 625 bpj adalah 0,19 bpj, artinya KHM kitosan oleh adanya ekstrak rosella menurun 250 kalinya. Menurut Raafat, Bargen, Haas, \& Sahl, (2008) Hasil perhitungan berdasarkan nilai KHM dari Tabel 1 di atas maka diperoleh nilai FICI (Fractional Inhibition Concentration Index) dari kombinasi kedua bahan tersebut yaitu $<0,50$ yang berarti aktivitas antibakteri terhadap $S$. aureus bersifat sinergis.

\section{KESIMPULAN}

Aktivitas antibakteri dari kombinasi ekstrak kelopak bunga rosella (Hibiscus sabdariffa L.) dan kitosan terhadap pertumbuhan Staphylococcus aureus menunjukkan efek sinergis dengan nilai Fractional Inhibition Concentration Index (FICI) sebesar <0,5.

\section{UCAPAN TERIMAKASIH}

Terima kasih atas fasilitas sarana dan prasarana dari laboratorium Biofarmaka Fakultas Farmasi UNHAS, sehingga penelitian ini dapat terlaksana.

\section{DAFTAR PUSTAKA}

Bakarnga-Via, I., Yande, H. K., Kouipou, R. M. T., Kanko, M. I. M., Boyom, F. F., Kammalac, T. N., \& Boyom, F. F. (2016). Effect of Combined Extracts from Different Plant Parts of Annona senegalensis on Antibacterial and Antifungal Activities. International Journal of Pharmacognosy and Phytochemical Research, 8(1), 162-166.

Borrás-Linares, I., Fernández-Arroyo, S., ArráezRoman, D., Palmeros-Suárez, P. A., Del ValDíaz, R., Andrade-Gonzáles, I., ... SeguraCarretero, A. (2015). Characterization of phenolic compounds, anthocyanidin, antioxidant and antimicrobial activity of 25 varieties of Mexican Roselle (Hibiscus sabdariffa). Industrial Crops \& Products, 69, 385-394.

https://doi.org/10.1016/j.indcrop.2015.02.053

Goy, R. C., Britto, D. De, \& Assis, O. B. G. (2009). A Review of the Antimicrobial Activity of Chitosan. Ciência E Tecnologia, 19(3), 241247.

Goy, R. C., Morais, S. T. B., \& Assis, O. B. G. (2016). Evaluation of the antimicrobial activity of chitosan and its quaternized derivative on $\mathrm{E}$. coli and S . aureus growth. Revista Brasileira de Farmacognosia, 26(1), 122-127. https://doi.org/10.1016/j.bjp.2015.09.010

Haeriah, Rahmatullah, M., Indardaya, A., Utomo, E., Novianti, \& Sartini. (2017). The Production of Chitosan from Shrimp Shell Waste and Its Formulation in Patch Dosage Form Combined with Aloe vera Extract as Antiinfection Agent. International Journal of Applied Biology, 1(1), 22-31.

Jabeur, I., Pereira, E., Barros, L., Calhelha, R. C., Soković, M., Oliveira, M. B. P. P., \& Ferreira, I. C. F. R. (2017). Hibiscus sabdariffa L. as a source of nutrients, bioactive compounds and colouring agents. Food Research International, 100, 717-723.

Jung, E., Kim, Y., \& Joo, N. (2013). Physicochemical properties and antimicrobial activity of Roselle 
( Hibiscus sabdariffa L .). Journal Science Food Agriculture, (93), 3769-3776.

Kong, M., Chen, X. G., Xing, K., \& Park, H. J. (2010). Antimicrobial properties of chitosan and mode of action: A state of the art review. International Journal of Food Microbiology, 144(1), 51-63.

Liu, K., Tsao, S., \& Yin, M. (2005). In vitro Antibacterial Activity of Roselle Calyx and Protocatechuic Acid. Phtyotherapy Research, 19(11), 942-945.

No, H. K., Park, N. Y., Lee, S. H., \& Meyers, S. P. (2002). Antibacterial activity of chitosans and chitosan oligomers with different molecular weights. International Journal of Food Microbiology, 74(1-2), 65-72.

Olga, P., Petar, K., Jelena, M., \& Srdjan, R. (2008). Screening method for detection of hydrocarbonoxidizing bacteria in oil-contaminated water and soil specimens. Journal of Microbiological Methods, 74, 110-113.

Raafat, D., Bargen, K. Von, Haas, A., \& Sahl, H. (2008). Insights into the Mode of Action of Chitosan as an Antibacterial Coumpound. Applied and Environmental Microbiology, 74(12), 3764-3773.

Sindi, H. A., Marshall, L. J., \& Morgan, M. R. A. (2014). Comparative Chemical and Biochemical Analysis of Extracts of Hibiscus sabdariffa. Food Chemistry, 164, 23-29.

Valgas, C., Souza, S. M. De, Smânia, E. F. A., \& Smânia Jr, A. (2007). Screening Methods To Determine Antibacterial Activity of Natural Products. Brazilian Journal of Microbiology, (38), 369-380. 